\title{
Treatment Adherence, Quality of Life and Clinical Variables in HIV/AIDS Infection*
}

\author{
Ana Reis ${ }^{\#}$, Marina Prista Guerra, Leonor Lencastre \\ Faculty of Psychology and Educational Sciences, Porto's University, Porto, Portugal. \\ Email: anacatarinareis@outlook.com \\ Received June $4^{\text {th }}, 2013$; revised July $4^{\text {th }}, 2013$; accepted August $4^{\text {th }}, 2013$ \\ Copyright (C) 2013 Ana Reis et al. This is an open access article distributed under the Creative Commons Attribution License, which \\ permits unrestricted use, distribution, and reproduction in any medium, provided the original work is properly cited.
}

\begin{abstract}
The purpose of the study was to analyze the relationship between treatment adherence, quality of life and clinical variables in HIV/AIDS Infection. The empirical study was conducted at two Portuguese hospitals (Porto and Lisbon) with a sample of 295 outpatients diagnosed with HIV/AIDS attending the Infectology service and on antiretroviral medication, during a 12-month period (February 2009 to February 2010). Data were collected by voluntary fulfillment of three questionnaires: one for socio-demographic variables, one to Assess Adherence to Antiretroviral Treatment-HIV and the Portuguese version of the WHOQOL-Bref to measure the quality of life (QoL). Clinical records were inspected in order to collect clinical information from the patients. The relationship between these variables was accessed by Student's t-test and ANOVA using Tukey and LSD as the post Hoc test. Regarding disease stages, the post Hoc analysis has showed that asymptomatic patients have a better level of adherence and quality of life when compared to those in more advanced stages of the disease. Undetectable viral load $<20$ copies $/ \mathrm{mL}$ and $\mathrm{T}$ CD4+ count $>500 \mathrm{cells} / \mathrm{mm}^{3}$ were also associated with higher QoL in all overall domains. Patients on NRTI + NNTRI regimens have higher adherence when compared to those on NRTI + PI regimens and higher QoL indexes when compared to twice daily regimens, patients on single dose per day regimens have higher adherence and higher QoL in overall domain. Patients experiencing adverse effects have lower QoL and lower adherence levels when compared to those not experiencing such events. We consider the multiplicity and the interaction of several determinants of influence in the adaptation process during the HIV/AIDS treatment. The results may have implications for the psychological intervention to improve the adherence's level to the antiretroviral therapy.
\end{abstract}

Keywords: Adherence; Quality of Life; HIV/AIDS

\section{Introduction}

The introduction of Highly Antiretroviral Therapy (HAART) has had a major impact on both life expectancy and quality of life of HIV-infected individuals [1-3]. Although clearly providing significant benefits, combination therapy is often associated with complicated regimens and non-negligible side effects. The new generation of HIV drugs offers the potential for long-term suppression of HIV replication, however the challenge is to encourage and enable patients to take these medications correctly, in order to achieve their maximum effect. Some studies have found that adherence lower than $95 \%$ can be associated with the development of viral resistance to medication

\footnotetext{
"The authors declare no conflict of interest in publishing this article. \#(PhD Grant-Scholarship for Doctor's Degree from the Science and Technology Foundation —SFRH/BD/43241/2008).
}

[4-7]. HAART regimes are composed of several drugs and distinct intake requirements (namely, with or without food, once or twice daily, the need for special storage conditions) for each drug within the regime, resulting in complex regimens. Many patients report difficulties to meet the requirements due to the complexity of treatment, requiring intervention and psychological support to overcome or improve the level of adherence to HAART [8].

If gaps in dose intake or other forms of inadequate adherence occur, the virus acquires the ability to replicate thereby increasing the risk of viral resistance [9]. The evidence on the association between clinical variables and HAART adherence is abundant [6,9-14] and indicates that adherence is associated with lower viral load, higher counts of lymphocytes T CD4+, asymptomatic stage, and less experience of adverse events of antiretroviral medication $[12,13,15]$. 
Considering the relevance of the topic, this work, which is part of a broader study [13] aims at analyzing the relationship between treatment adherence, quality of life, and HIV/AIDS infection surrogate markers.

\section{Method}

\subsection{Ethics Statement}

The study received favorable ethical statement from the Portuguese Data Protection (CNPD) as well as by the Joaquim Urbano's hospital (Porto, Portugal) and Curry Cabral's hospital (Lisboa, Portugal) ethical committees. The participation was voluntary and the informed consent was signed by all participants.

\subsection{Data Collection}

The data was collected between February of 2009 and February of 2010, in two major infectious disease centers in Portugal (Joaquim Urbano Hospital in Porto and Curry Cabral Hospital in Lisbon).

Patients on the same antiretroviral regimen for at least 3 months were invited, by the infectious disease specialist, to participate in the study.

The research protocol was completed, in the presence of a psychologist, at the end of the physician appointment. This research protocol consisted of patients' clinical records inspection in order to collect participants' clinical information and the fulfillment of three questionnaires: one for socio-demographic variables, one to Assess Adherence to Antiretroviral Treatment-HIV (Portuguese adaptation of the CEAT-VIH) $[6,16]$ and one to measure the quality of life $(\mathrm{QoL})$ (Portuguese version of the WHOQOL-Bref) [17].

\subsection{Instruments}

\subsubsection{Questionnaire Sample Characterization}

This questionnaire includes information on both sociodemographic variables (sex, age, civil status, occupation, schooling) and clinical (mode of transmission, time since infection, HIV stage [18], viral load, lymphocyte T CD4+ count, presence of adverse events of antiretroviral treatment and current antiretroviral regimen.

\subsubsection{Questionnaire for Assessing Adherence to Antiretroviral Treatment (CEAT-VIH, in the Original)}

The CEAT-VIH is a 20 items multidimensional instrument, of self-administration, validated for antiretroviral regimen adherence assessment in HIV infected adult individuals. This quick and simple tool addresses the main factors associated to adherence behaviors. The questionnaire score varies between 19 and 81 and a higher score indicates a higher level of adherence to treatment $[6,19]$.
The CEAT-VIH was originally developed in Spain [6] and later adapted to Brazil [7] Colombia [20], Mexico [21], Peru [22] and Roménia [23]. In the present study $[12,16]$ the CEAT-VIH was adapted to Portugal's Portuguese and the internal consistency was assessed through the Cronbach's alpha ( 0.89 for the present study).

\subsubsection{World Health Organization Quality of Life- WHOQOL-Bref}

The WHOQOL-Bref, short version of WHOQOL-100, is a tool of quality of life assessment organized in four domains and a general feature (two items) regarding the assessing of global quality of life [17]. The internal consistency for each domain was assessed through the Cronbach's alpha and it was the following: physical health (0.78), psychological (0.79), social relationships (0.79) and environment $(0.83)$. The questionnaire score varies between 0 and 100 with a higher score representing better quality of life.

\subsection{Participants}

The sample was collected randomly in reference centers mentioned above and it's a non-representative sample.

As presented in Table 1, the sample consists of 295 participants diagnosed with HIV/AIDS Infection both female $(\mathrm{n}=105 ; 35.6 \%)$ and male $(\mathrm{n}=190 ; 64.4 \%)$ and aged between 19 and 81 years [Mean $(\mathrm{M})=40.9$ years, Standard Deviation $(\mathrm{SD})=9.5$ ]. Regarding marital status, $47.5 \%$ are single, $36.6 \%$ are married and/or cohabitate) and $12.9 \%$ are separated and/or divorced. Regarding education, participants is distributed as follows: Basic Education ${ }^{\dagger}: 1$ st cycle $(\mathrm{n}=75 ; 25.4 \%)$, 2nd cycle $(\mathrm{n}=70$; $23.7 \%)$, 3rd cycle $(\mathrm{n}=72 ; 24.4 \%)$; Secondary education $(\mathrm{n}=37 ; 12.5 \%)$ and Tertiary education $(\mathrm{n}=26 ; 8.8 \%)$. In what concerns occupation, $33.6 \%(n=99)$ of the participants are professionally active, $39.3 \%(\mathrm{n}=116)$ unemployed and $17.3 \%$ are retired $(n=51)$. The remaining percentage correspond to domestic workers, people who have never worked or are currently on sick leave $(n=29$; 9.8\%).

According to the data presented in Table 1 the most frequent transmission mode was heterosexual sex $(\mathrm{n}=$ $159 ; 52.9 \%)$. At the time of interview, $56.9 \%$ participants were in stage A1 (asymptomatic) of HIV infection [13] and the average time of infection was 103.4 months (SD $=60.2$ ). Of the total number of participants included in the sample, regarding clinical indicators of HIV/AIDS infection, $34.6 \%$ have undetectable viral load $(<20$ copies $/ \mathrm{ml}$ ). Considering participants who are not with undetectable viral load it was found that only $5.08 \%$ had values above 100,000 copies. The average lymphocyte $T$

${ }^{\dagger}$ In Portugal, Basic Education consists of nine years of schooling divided into three sequential cycles of education of four, two and three years. 
Table 1. Clinical data $(n=295)$.

\begin{tabular}{|c|c|c|c|c|c|c|c|}
\hline Clinical data & Subcategories & $n$ & $\%$ & Min & $\operatorname{Max}$ & $M$ & $S D$ \\
\hline \multicolumn{8}{|l|}{ Mode of transmission } \\
\hline & Heterosexual & 156 & 52.9 & & & & \\
\hline & Homosexual & 36 & 12.2 & & & & \\
\hline & IVDU & 99 & 33.6 & & & & \\
\hline \multicolumn{8}{|c|}{ Disease stage CDC (Centre for Disease Control) } \\
\hline & Asymptomatic & 168 & 56.9 & & & & \\
\hline & Symptomatic & 49 & & & & & \\
\hline & AIDS & 78 & & & & & \\
\hline Time since infection (in months) & & & & 4 & 252 & 103.4 & 60.2 \\
\hline \multirow[t]{7}{*}{ Viral load (HIV RNA cps/mL) } & & & & $<20$ & 750,000 & 20688.3 & 91614.6 \\
\hline & $<20$ & 102 & 34.6 & & & & \\
\hline & $20-50$ & 128 & 43.4 & & & & \\
\hline & $51-500$ & 20 & 6.8 & & & & \\
\hline & $501-10,000$ & 14 & 4.7 & & & & \\
\hline & $10,001-30,000$ & 1 & 0.3 & & & & \\
\hline & $>100,000$ & 15 & 5.08 & & & & \\
\hline \multirow[t]{5}{*}{ CD4+ count } & & & & 8 & 1556 & 454.4 & 308.4 \\
\hline & $<200$ & 65 & 22.0 & & & & \\
\hline & $200-350$ & 63 & 21.4 & & & & \\
\hline & $351-500$ & 65 & 22.0 & & & & \\
\hline & $>500$ & 102 & 34.6 & & & & \\
\hline \multicolumn{8}{|l|}{ Third agent Drug Class } \\
\hline & $\mathrm{NRTI}^{*}+\mathrm{NNRTI}^{* *}$ & 194 & 66.4 & & & & \\
\hline & $\mathrm{NRTI}+\mathrm{PI}^{* * *}$ & 98 & 33.6 & & & & \\
\hline \multirow[t]{4}{*}{ Number of doses/day } & & & & 1 & 3 & 1.5 & 0.5 \\
\hline & 1 & 158 & 53.6 & & & & \\
\hline & 2 & 134 & 45.4 & & & & \\
\hline & 3 & 3 & 1.0 & & & & \\
\hline \multirow[t]{6}{*}{ Number of pills/day } & & & & 1 & 9 & 3.7 & 1.8 \\
\hline & 1 & 26 & 8.8 & & & & \\
\hline & 2 & 53 & 18.0 & & & & \\
\hline & 3 & 90 & 30.5 & & & & \\
\hline & 4 & 37 & 12.5 & & & & \\
\hline & $>4$ & 89 & 30.2 & & & & \\
\hline \multicolumn{8}{|c|}{ Adverse events of antiretroviral medication } \\
\hline & yes & 113 & & & & & \\
\hline & No & 182 & & & & & \\
\hline
\end{tabular}

*Nucleoside reverse transcriptase inhibitors; ${ }^{* *}$ Non nucleoside reverse transcriptase inhibitors; ${ }^{* * *}$ Protease inhibitors. 
CD4+ count was $455.8(\mathrm{SD}=308.4)$, ranging between and 1556 . Of the total participants, $22 \%$ presented lymphocyte T CD4+ count $<200$. The most common antiretroviral regimen is a combination of two Nucleoside Reverse Transcriptase Inhibitors (NRTI) with one Non-nucleoside Reverse Transcriptase Inhibitors (NNRTI) (53.9\%). The simplest regimen provides one pill per day and $8.8 \%$ of the participants are under that regimen. $53.6 \%$ of the participants are on a daily regimen and the average number of pills per day is $3.7(\mathrm{SD}=1.8)$. Finally, $38.3 \%$ of participants reported experiencing side effects related to antiretroviral therapy.

\subsection{Procedures}

\section{Data Analysis}

For data analysis it was used the informatics program SPSS (Statistical Package for Social Sciences-version 17) to treat the data statistically. At first the data analysis included a description of the variables in study. Then, for the study of adherence and quality of life differences and considering the clinical variables, it was used the parametric statistics after the normality of the sample was tested and assumed ( $t$ tests of Student and ANOVA analysis with post-hoc Tukey and LSD).

\section{Results}

Tables 2 to 10 present the estimated association between the variables under analysis (adherence and quality of life) and the presumed relevant factors (clinical variables). Overall, results suggest a statistically significant association between clinical variables considered (viral load, lymphocyte T CD4+ count, antiretroviral regimen, and number of intakes per day, number of pills per day and adverse events of antiretroviral medication at the time of the data collection) and adherence and quality of life.

As shown in Table 2, it can be seen that there are significant differences in adherence and in all domains of quality of life, including the general facet, depending on the CDC HIV stage [13]. In addition, Tukey's tests were calculated to detect the direction of these differences having been found that infected individuals in an asymptomatic stage have better compliance and higher scores in all domains of quality of life. There were no statistically significant differences between the symptomatic patients and those undergoing AIDS (Table 3).

With regard to viral load, it can be verified by reading Table 4 that adherence and quality of life are higher in participants with undetectable viral load, except for the field of social relations in which no statistically significant differences were found. With respect to CD4+ T cell count, statistically significant differences in adherence and in all domains of quality of life, except for the psychological domain (Table 5), were obtained. Through the Tukey's test $(p<0.001)$ it was found that participants with CD4 $+>500 / \mathrm{mm}^{3}$ have higher adherence and better quality of life (Table 6).

In terms of the therapeutic regimen, Table 7 shows that participants with NRTI + NNRTI prescription present higher compliance and better quality of life, in the physical, environment and general facet. Table 7 also indicates that participants who reported experiencing side effects of antiretroviral therapy have lower levels of adherence and worse quality of life.

With regard to the number of intakes per day, there are statistically significant differences in adherence and quality of life for participants in a single dose regimen, except for the domain of social relationships (Table 8).

Concerning the number of tablets per day there are statistically significant differences in adherence and in

Table 2. Mean differences (One-Way ANOVA) in treatment adherence and quality of life according to HIV stage (CDC).

\begin{tabular}{|c|c|c|c|c|c|c|c|c|}
\hline \multicolumn{9}{|c|}{ HIV stage (CDC) } \\
\hline & \multirow{2}{*}{\multicolumn{2}{|c|}{$\begin{array}{l}\text { Asymptomatic } \\
\qquad(\mathrm{n}=168)\end{array}$}} & \multirow{2}{*}{\multicolumn{2}{|c|}{$\begin{array}{c}\text { Symptomatic } \\
\qquad(\mathrm{n}=49)\end{array}$}} & \multirow{2}{*}{\multicolumn{2}{|c|}{$\begin{array}{c}\text { AIDS } \\
(\mathrm{n}=78)\end{array}$}} & \multirow[b]{3}{*}{$\boldsymbol{F}$} & \multirow[b]{3}{*}{$p$} \\
\hline & & & & & & & & \\
\hline & $M$ & $S D$ & $M$ & $S D$ & $M$ & $S D$ & & \\
\hline Adherence & 74.18 & 8.62 & 65.57 & 10.72 & 68.72 & 12.34 & 17.29 & $<0.001$ \\
\hline General QoL ${ }^{*}$ & 57.07 & 20.46 & 50.77 & 22.45 & 45.83 & 20.11 & 8.19 & $<0.001$ \\
\hline \multicolumn{9}{|l|}{ QoL domains } \\
\hline Physical health & 63.88 & 18.40 & 54.45 & 16.01 & 54.62 & 15.13 & 10.62 & $<0.001$ \\
\hline Psychological & 61.01 & 17.14 & 53.49 & 16.95 & 53.47 & 18.66 & 6.68 & 0.001 \\
\hline Social relationships & 55.51 & 22.22 & 48.98 & 20.03 & 45.19 & 20.12 & 6.70 & 0.001 \\
\hline Environment & 56.62 & 16.27 & 51.72 & 16.29 & 49.80 & 18.20 & 4.93 & 0.008 \\
\hline
\end{tabular}

${ }^{*}$ Quality of life. 
Table 3. Mean differences (One-Way ANOVA) in treatment adherence and quality of life according to HIV stage (CDC)Post-hoc Tukey.

\begin{tabular}{|c|c|c|c|c|}
\hline & HIV stage (CDC) & HIV stage (CDC) & Mean difference & $p$ \\
\hline \multirow{3}{*}{ Adherence } & \multirow[b]{2}{*}{ Asymptomatic } & Symptomatic & 8.61 & $<0.001$ \\
\hline & & AIDS & 5.46 & $<0.001$ \\
\hline & Symptomatic & AIDS & -3.15 & 0.203 \\
\hline \multirow{3}{*}{ General QoL* } & \multirow{2}{*}{ Asymptomatic } & Symptomatic & 6.30 & 0.15 \\
\hline & & AIDS & 11.24 & $<0.001$ \\
\hline & Symptomatic & AIDS & 4.93 & 0.39 \\
\hline \multicolumn{5}{|l|}{ QoL domains: } \\
\hline \multirow{3}{*}{ Physical health } & \multirow{2}{*}{ Asymptomatic } & Symptomatic & 9.34 & 0.002 \\
\hline & & AIDS & 9.26 & $<0.001$ \\
\hline & Symptomatic & AIDS & -0.18 & 0.99 \\
\hline \multirow{3}{*}{ Psychological } & \multirow{2}{*}{ Asymptomatic } & Symptomatic & 7.53 & 0.02 \\
\hline & & AIDS & 7.54 & 0.005 \\
\hline & Symptomatic & AIDS & 0.014 & 1.00 \\
\hline \multirow{3}{*}{ Social relationships } & \multirow{2}{*}{ Asymptomatic } & Symptomatic & 6.26 & 0.15 \\
\hline & & AIDS & 10.31 & 0.001 \\
\hline & Symptomatic & AIDS & 3.79 & 0.59 \\
\hline \multirow{3}{*}{ Environment } & \multirow{2}{*}{ Asymptomatic } & Symptomatic & 4.90 & 0.17 \\
\hline & & AIDS & 6.82 & 0.009 \\
\hline & Symptomatic & AIDS & 1.92 & 0.81 \\
\hline
\end{tabular}

${ }^{*}$ Quality of life.

Table 4. Mean differences (One-Way ANOVA) in treatment adherence and quality of life according to the viral load.

\begin{tabular}{|c|c|c|c|c|c|c|}
\hline & \multicolumn{6}{|c|}{ Viral load } \\
\hline & \multicolumn{2}{|c|}{$<20$} & \multicolumn{2}{|c|}{$>20$} & \multirow[b]{3}{*}{$t$} & \multirow[b]{3}{*}{$p$} \\
\hline & \multicolumn{2}{|c|}{$(n=102)$} & \multicolumn{2}{|c|}{$(n=193)$} & & \\
\hline & $M$ & $S D$ & $M$ & $S D$ & & \\
\hline Adherence & 77.43 & 5.20 & 68.07 & 11.33 & 9.71 & $<0.001$ \\
\hline General QoL ${ }^{*}$ & 56.37 & 18.08 & 51.30 & 22.53 & 2.10 & 0.04 \\
\hline \multicolumn{7}{|l|}{ QoL domains: } \\
\hline Physical health & 66.60 & 17.65 & 56.31 & 16.81 & 4.91 & $<0.001$ \\
\hline Psychological & 63.97 & 16.03 & 54.49 & 17.95 & 4.47 & $<0.001$ \\
\hline Social relationships & 53.76 & 21.83 & 50.60 & 21.68 & 1.19 & 0.24 \\
\hline Environment & 57.02 & 14.46 & 52.41 & 18.07 & 2.38 & 0.02 \\
\hline
\end{tabular}

*Quality of life.

the physical and environment domains and on the overall quality of life facet in favor of participants who take 1 pill per day (Table 9).
It was carried out a post-hoc LSD $(p<0.001)$ and it was found that the statistically significant differences regarding adherence are among the participants taking 1 
Table 5. Mean differences (Student's t-test) in treatment adherence and quality of life according to the CD4+ count.

\begin{tabular}{|c|c|c|c|c|c|c|c|c|c|c|}
\hline & \multicolumn{10}{|c|}{ CD4+ count } \\
\hline & \multicolumn{2}{|c|}{$\begin{array}{c}<200 \\
(n=65)\end{array}$} & \multicolumn{2}{|c|}{$\begin{array}{c}200-350 \\
(n=63)\end{array}$} & \multicolumn{2}{|c|}{$\begin{array}{c}351-500 \\
(n=65)\end{array}$} & \multicolumn{2}{|c|}{$\begin{array}{c}>500 \\
(n=102)\end{array}$} & \multirow[b]{2}{*}{$F$} & \multirow[b]{2}{*}{$p$} \\
\hline & $M$ & $S D$ & $M$ & $S D$ & $M$ & $S D$ & $M$ & $S D$ & & \\
\hline Adherence & 67.14 & 12.61 & 71.21 & 10.53 & 71.52 & 9.56 & 73.88 & 9.19 & 5.59 & 0.001 \\
\hline General QoL ${ }^{*}$ & 43.85 & 19.15 & 51.29 & 19.89 & 55.38 & 21.19 & 58.33 & 21.50 & 6.95 & $<0.001$ \\
\hline \multicolumn{11}{|l|}{ QoL domains } \\
\hline Physical health & 54.89 & 14.29 & 57.20 & 18.51 & 61.76 & 17.69 & 63.48 & 18.59 & 3.94 & 0.009 \\
\hline Psychological & 53.97 & 18.67 & 55.95 & 15.50 & 59.42 & 18.41 & 60.25 & 18.06 & 2.06 & 0.11 \\
\hline Environment & 49.90 & 17.30 & 51.34 & 14.82 & 54.66 & 17.23 & 57.84 & 17.34 & 3.63 & 0.01 \\
\hline
\end{tabular}

*Quality of life.

pill a day and those taking 2 , between those who take 1 and 3 , between those who take 1 and 4 and those who take 1 and more than 4 tablets per day. For the overall quality of life facet it was verified that the statistically significant differences are among participants taking 1 pill a day and those taking 2, among those taking 1 and 3 , among those taking 1 and 4, among those who take 1 and more than 4 , among those taking 2 and 4 and among those taking more than 4 tablets per day (Table 10).

\section{Discussion}

The aim of this study was to analyze the relationship between treatment adherence, quality of life and clinical variables in HIV/AIDS infection. Some disease and treatment related variables appear to compromise adherence and quality of life levels. It was found statistically significant differences in adherence and quality of life in relation to HIV stage and biological markers of HIV infection-viral load and on the CD4+ T cell count, which is in agreement with other studies $[6,9,10]$. With respect to disease stage, while some studies indicate improved adherence in symptomatic and AIDS stage patients [11,24, $25]$ that does not happen in our study: our results suggest that asymptomatic subjects show a higher adherence level. One possible explanation for this result is that fear of future complications may create an incentive for increased adherence in asymptomatic patients.

Considering the biological markers it was found that subjects with undetectable viral load and CD4 + T > 500 cell count have better levels of adherence and better insight of quality of life. These results are in line with those presented in the literature on the benefits of antiretroviral therapy in reducing viral load and restoration of immunity $[6,9,10,14]$.

With respect to therapeutic regimen, the available evi- dence suggests that want both the number of daily intakes [25] and the number of pills per day [26,27] are of relevance in increasing the probability of higher adherence levels. Our results confirm that evidence, indeed we find that patients on a single tablet regimen have both higher adherence and higher quality of life. These results reinforce the importance of the complexity of the treatment as adherence barrier [28]. Further, they reinforce the fact the lower the level of interference of treatment in daily life, the higher the average adherence level $[6,10$, 29].

With regard to side effects, as expected participants who reported experiencing side effects associated with antiretroviral treatment are found to have a lower adherence levels and worse quality of life. This result is entirely consistent with prior studies on the impact side effects can have on the adherence and quality of life [12, 30]. Indeed, side effects (often severe and complex) are described in the literature as predictors of poor adherence [29]. It is, thus, important to monitor side effects when starting or switching therapy [31].

\section{Conclusions}

Clinical variables and regimen characteristics were found to be associated with adherence and QoL. We were able to find significant evidence of positive association between treatment simplification in adherence and QoL. For instance, reducing the number of pills and the number of daily doses is found to be associated with higher adherence and better QoL. The results also reinforce the widely described in the literature barrier to adequate adherence generated by treatment complexity. These aspects should thus be considered when defining interventions to improve adherence to antiretroviral therapy.

The study does have some limitations. Adherence was 
Table 6. Mean differences (Student's t-test) in treatment adherence and quality of life according to the CD4+ cell countPost-hoc Tukey.

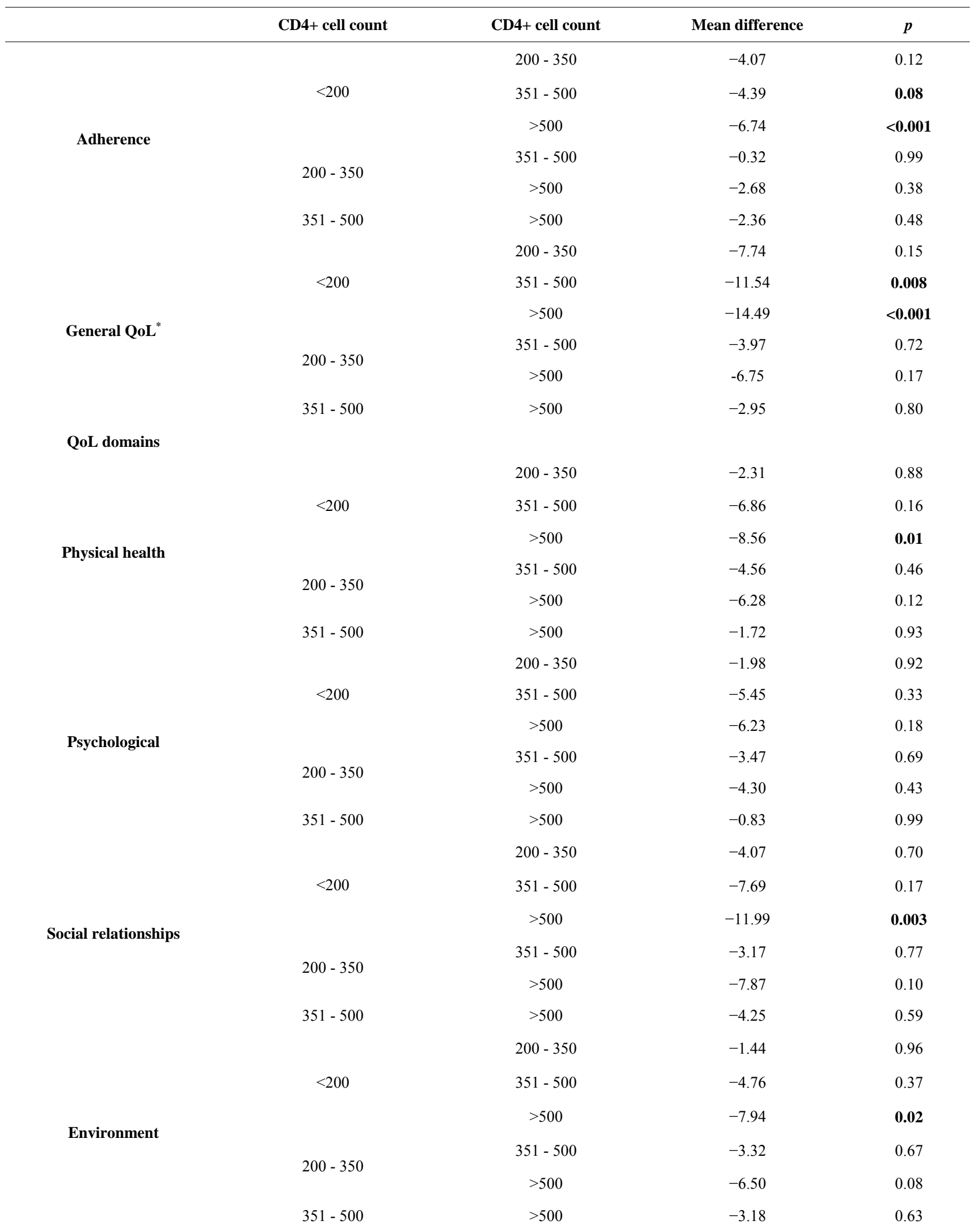

${ }^{*}$ Quality of life. 
Table 7. Mean differences (Student's t-test) in treatment adherence and quality of life according to the class of drug and adverse events of antiretroviral medication.

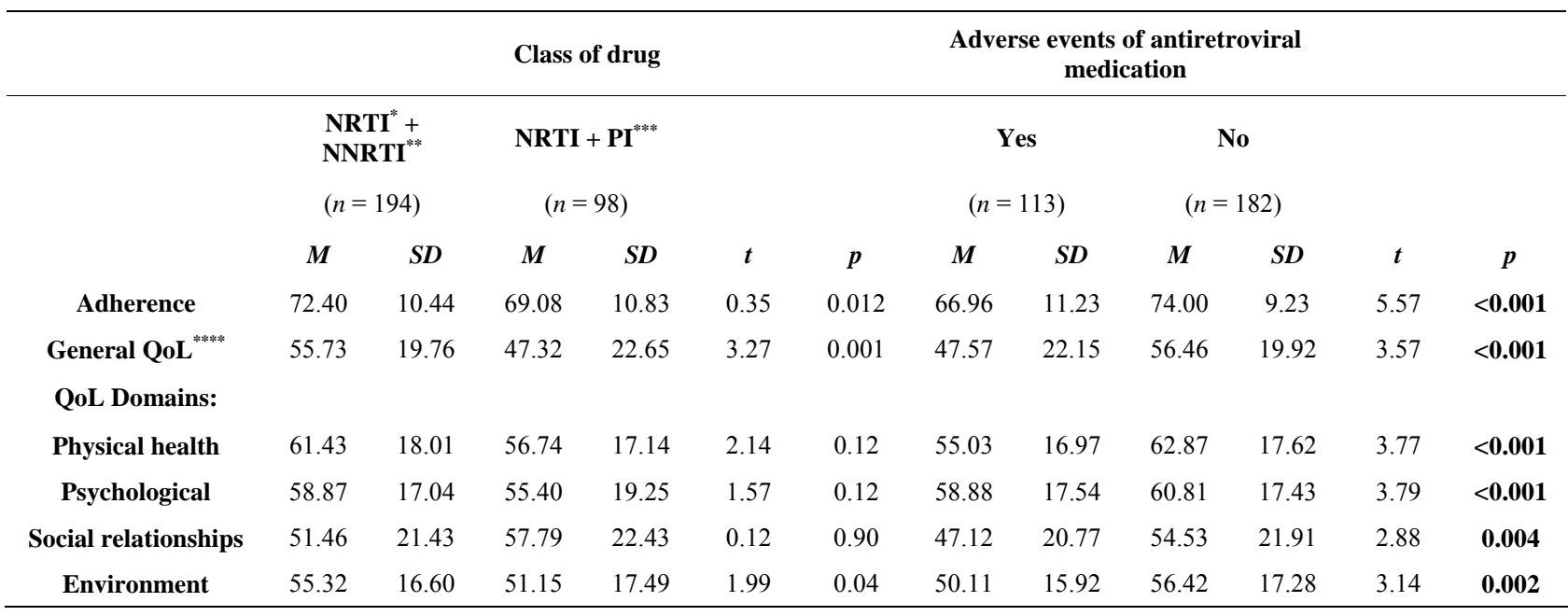

*Nucleoside reverse transcriptase inhibitors; ${ }^{* *}$ non nucleoside reverse transcriptase inhibitors; ${ }^{* * *}$ protease inhibitors; ${ }^{* * * *}$ quality of life.

Table 8. Mean differences (Student's t-test) in treatment adherence and quality of life according to the number of doses per day.

\begin{tabular}{|c|c|c|c|c|c|c|}
\hline \multicolumn{7}{|c|}{ Number of doses per day } \\
\hline & \multirow{2}{*}{\multicolumn{2}{|c|}{$\begin{array}{c}1 \\
(n=158)\end{array}$}} & \multirow{2}{*}{\multicolumn{2}{|c|}{$\begin{array}{c}2 \\
(n=134)\end{array}$}} & \multirow[b]{3}{*}{$t$} & \multirow[b]{3}{*}{$p$} \\
\hline & & & & & & \\
\hline & $M$ & $S D$ & $M$ & $S D$ & & \\
\hline Adherence & 73.54 & 9.56 & 6893 & 11.18 & 3.76 & $<0.001$ \\
\hline General QoL ${ }^{*}$ & 55.93 & 20.14 & 4963 & 22.16 & 2.55 & 0.001 \\
\hline \multicolumn{7}{|l|}{ QoL domains } \\
\hline Physical health & 61.84 & 17.25 & 57.41 & 18.07 & 2.14 & 0.03 \\
\hline Psychological & 60.86 & 16.28 & 54.32 & 19.00 & 3.13 & 0.002 \\
\hline Social relationships & 52.06 & 21.99 & 51.24 & 21.66 & 0.32 & 0.75 \\
\hline Environment & 56.59 & 16.01 & 50.93 & 17.80 & 2.86 & 0.005 \\
\hline
\end{tabular}

${ }^{*}$ Quality of life.

Table 9. Mean differences (One-Way ANOVA) in treatment adherence and quality of life according to the number of pills per day.

\begin{tabular}{|c|c|c|c|c|c|c|c|c|c|c|c|c|}
\hline \multicolumn{13}{|c|}{ Number of pills per day } \\
\hline & \multirow{2}{*}{\multicolumn{2}{|c|}{$\begin{array}{c}1 \\
(n=26)\end{array}$}} & \multirow{2}{*}{\multicolumn{2}{|c|}{$\begin{array}{c}2 \\
(n=53)\end{array}$}} & \multirow{2}{*}{\multicolumn{2}{|c|}{$\begin{array}{c}3 \\
(n=90)\end{array}$}} & \multirow{2}{*}{\multicolumn{2}{|c|}{$\begin{array}{c}4 \\
(n=37)\end{array}$}} & \multirow{2}{*}{\multicolumn{2}{|c|}{$\begin{array}{c}>4 \\
(n=89)\end{array}$}} & \multirow[b]{3}{*}{$\boldsymbol{F}$} & \multirow[b]{3}{*}{$p$} \\
\hline & & & & & & & & & & & & \\
\hline & $M$ & $S D$ & $M$ & $S D$ & $M$ & $S D$ & $M$ & $S D$ & $M$ & $S D$ & & \\
\hline Adherence & 78.04 & 5.11 & 73.11 & 10.84 & 71.63 & 10.57 & 68.70 & 9.27 & 69.01 & 11.36 & 4.84 & 0.001 \\
\hline General QoL ${ }^{*}$ & 64.90 & 13.70 & 58.25 & 19.14 & 53.75 & 21.97 & 46.96 & 18.96 & 48.31 & 22.39 & 4.98 & 0.001 \\
\hline \multicolumn{13}{|l|}{ QoL domains } \\
\hline Physical health & 66.62 & 16.93 & 63.14 & 16.59 & 60.63 & 18.42 & 55.12 & 16.38 & 56.98 & 17.82 & 2.83 & 0.03 \\
\hline Psychological & 61.38 & 14.56 & 60.61 & 16.09 & 58.56 & 18.07 & 54.28 & 17.19 & 55.66 & 19.50 & 1.31 & 0.27 \\
\hline Social relationships & 53.53 & 22.51 & 51.10 & 19.86 & 51.67 & 22.66 & 50.00 & 19.64 & 52.25 & 22.85 & 0.13 & 0.97 \\
\hline Environment & 58.05 & 14.80 & 57.96 & 15.87 & 54.90 & 17.75 & 49.58 & 15.47 & 51.40 & 17.62 & 2.33 & 0.05 \\
\hline
\end{tabular}

*Quality of life. 
Table 10. Mean differences (One-Way ANOVA) in treatment adherence and quality of life according to the number of pills per day-Post-hoc LSD.

\begin{tabular}{|c|c|c|c|c|}
\hline & Pills per day & Pills per day & Mean difference & $p$ \\
\hline \multirow{14}{*}{ Adherence } & \multirow{4}{*}{1} & 2 & 4.93 & 0.048 \\
\hline & & 3 & 6.41 & 0.006 \\
\hline & & 4 & 9.34 & 0.001 \\
\hline & & $>4$ & 9.03 & $<0.001$ \\
\hline & \multirow{3}{*}{2} & 3 & 1.48 & 0.41 \\
\hline & & 4 & 4.41 & 0.048 \\
\hline & & $>4$ & 4.10 & 0.02 \\
\hline & \multirow{2}{*}{3} & 4 & 2.93 & 0.15 \\
\hline & & $>4$ & 2.62 & 0.09 \\
\hline & 4 & $>4$ & -0.31 & 0.88 \\
\hline & & 2 & 6.65 & 0.18 \\
\hline & & 3 & 11.15 & 0.02 \\
\hline & 1 & 4 & 17.94 & 0.001 \\
\hline & & $>4$ & 11.59 & $<0.001$ \\
\hline \multirow{6}{*}{ General QoL ${ }^{*}$} & \multirow{3}{*}{2} & 3 & 4.51 & 0.21 \\
\hline & & 4 & 11.23 & 0.01 \\
\hline & & $>4$ & 9.94 & 0.006 \\
\hline & \multirow{2}{*}{3} & 4 & 6.80 & 0.09 \\
\hline & & $>4$ & 5.45 & 0.08 \\
\hline & 4 & $>4$ & -1.34 & 0.74 \\
\hline \multicolumn{5}{|l|}{ QoL domains } \\
\hline \multirow{9}{*}{ Physical health } & \multirow{4}{*}{1} & 2 & 3.21 & 0.45 \\
\hline & & 3 & 5.90 & 0.13 \\
\hline & & 4 & 11.51 & 0.01 \\
\hline & & $>4$ & 9.64 & 0.01 \\
\hline & \multirow{3}{*}{2} & 3 & 2.78 & 0.36 \\
\hline & & 4 & 8.30 & 0.03 \\
\hline & & $>4$ & 6.43 & 0.04 \\
\hline & \multirow{2}{*}{3} & 4 & 5.52 & 0.12 \\
\hline & & $>4$ & 3.65 & 0.17 \\
\hline \multirow{11}{*}{ Psychological } & 4 & $>4$ & -1.87 & 0.59 \\
\hline & \multirow{4}{*}{1} & 2 & 0.77 & 0.86 \\
\hline & & 3 & 2.81 & 0.48 \\
\hline & & 4 & 7.09 & 0.12 \\
\hline & & $>4$ & 5.71 & 0.15 \\
\hline & \multirow{3}{*}{2} & 3 & 2.05 & 0.51 \\
\hline & & 4 & 6.33 & 0.98 \\
\hline & & $>4$ & 4.95 & 0.11 \\
\hline & \multirow{2}{*}{3} & 4 & 4.30 & 0.22 \\
\hline & & $>4$ & 2.90 & 0.28 \\
\hline & 4 & $>4$ & -1.39 & 0.69 \\
\hline
\end{tabular}




\begin{tabular}{|c|c|c|c|c|}
\hline \multirow{10}{*}{ Social relationships } & \multirow{4}{*}{1} & 2 & 2.43 & 0.64 \\
\hline & & 3 & 1.86 & 0.70 \\
\hline & & 4 & 3.53 & 0.53 \\
\hline & & $>4$ & 1.28 & 0.80 \\
\hline & \multirow{3}{*}{2} & 3 & -0.57 & 0.88 \\
\hline & & 4 & 1.10 & 0.81 \\
\hline & & $>4$ & -1.15 & 0.76 \\
\hline & \multirow{2}{*}{3} & 4 & 1.68 & 0.70 \\
\hline & & $>4$ & -0.58 & 0.86 \\
\hline & 4 & $>4$ & -2.25 & 0.60 \\
\hline \multirow{10}{*}{ Environment } & \multirow{4}{*}{1} & 2 & 0.09 & 0.98 \\
\hline & & 3 & 3.16 & 0.40 \\
\hline & & 4 & 8.48 & 0.05 \\
\hline & & $>4$ & 6.65 & 0.08 \\
\hline & \multirow{3}{*}{2} & 3 & 3.06 & 0.30 \\
\hline & & 4 & 8.38 & 0.02 \\
\hline & & $>4$ & 6.56 & 0.03 \\
\hline & \multirow[t]{2}{*}{3} & 4 & 5.32 & 0.11 \\
\hline & & $>4$ & 3.50 & 0.17 \\
\hline & 4 & $>4$ & -1.83 & 0.58 \\
\hline
\end{tabular}

*Quality of life.

assessed through a self-reporting adherence questionnaire and these results then confronted with biological markers (patient's viral load and CD4 count). Despite concerns that self-reporting may overestimate adherence, it has been demonstrated that self-reported adherence has been consistently correlated with viral load and clinical outcomes in HIV treatment $[6,12,16]$ and has been deemed a robust and appropriate indicator of adherence.

This study is a cross-sectional study, which measured adherence and QoL at a single time point. However, adherence and QoL are dynamic processes that may change over time. Longitudinal studies with a wider range of respondents and the use of a combination of adherence assessment tools are necessary to understand adherence and QoL over time and to explore the factors that influence adherence to antiretroviral therapy in the longer term, which could most likely reduce the risk of overestimation [32].

\section{Acknowledgements}

The authors would like to thank Gilead Sciences Ltd., for supporting the manuscript preparation.

\section{REFERENCES}

[1] O. Alvis, L. De Coll, L. Chumbimune, C. Díaz, J. Díaz, et al., "Factores Associados a la No Adherencia al Tratamento Antirretroviral en Adultos Infectados con el VIH/ SIDA," Anales de la Facultad de Medicina, Vol. 70, No. 4, 2009, pp. 266-272.

[2] R. Sarmento, "Terapêutica Anti-Retrovírica Inicial," In H. Lecour and R. Sarmento, Eds., Infeção VIH/SIDA: 2 Curso de Pós-Graduação, Portugal, 2004, pp. 327-338.

[3] P. A. Volderbing, "Início da Terapêutica Para o VIH," Postgraduate Medicine, Vol. 22, No. 1, 2004, pp. 83-90.

[4] M. A. Chesney, J. R. Ickovics, D. B. Chambers, A. L. Gifford, J. Neidig, et al., "Self-Reported Adherence to Antiretroviral Medications among Participants in HIV Clinical Trials: The AACTG Adherence Instruments," AIDS CARE, Vol. 12, No. 3, 2000, pp. 255-266.

[5] E. Gir, C. G. Vaichulonis and M. D. Oliveira, "Adesão à Terapêutica Antirretroviral por Indivíduos com HIV/ AIDS Assistidos em uma Instituição do Interior Paulista," Revista Latino-Americana de Enfermagem, Vol. 13, No. 5, 2005.

[6] E. Remor, "Valoración de la Adhesión al Tratamiento Antirretroviral en Pacientes VIH+," Psicothema, Vol. 14, No. 2, 2002, pp. 262-267.

[7] E. Remor, J. Milner-Moskovics and G. Preussler, "Adaptação Brasileira do "Cuestionario para la Evaluación de la Adhesión al Tratamiento Antirretroviral'," Revista de Saúde Pública, Vol. 41, No. 5, 2007, pp. 685-694.

[8] E. Remor, "Intervención del Psicólogo en una Unidad de Tratamiento de Pacientes con Infección por VIH/SIDA," 
In: E. Remor, P. Arranz and S. Ulla, Eds., El Psicólogo en el Ámbito Hospitalario, DDB, Bilbao, 2003, pp. 309348.

[9] R. Margalho, M. Pereira, S. Ouakinin and M. C. Canavarro, "Adesão à HAART, Qualidade de vida e Sintomatologia Psicopatológica em Doentes Infetados pelo VIH/ SIDA," Acta Med Port, Vol. 24, No. S2, 2011, pp. 539548.

[10] A. Amassari, M. P. Trotta, R. Murri, F. Castelli, P. Narciso, et al., "Correlates and Predictors of Adherence to Highly Active Antiretroviral Therapy: Overview of PubLished Literature," Journal of Acquired Immune Deficiency Syndromes, Vol. 31, No. 3, 2002, pp. 123-127.

[11] X. Gao, "The Relationship of Disease Severity, Health Beliefs and Medication Adherence among HIV Patients," Master Thesis, West Virginia University, Morgantown, 1999.

[12] A. Reis, “Adesão Terapêutica na Infeção pelo vírus da Imunodeficiência Humana (Tese de Mestrado não Publicada," Faculdade de Psicologia e de Ciências da Educação da Universidade do Porto, Porto, 2007.

[13] A. Reis, "Avaliação da Adesão Terapêutica na Infeção VIH/SIDA e Compreensão de Variáveis Psicológicas Associadas," Tese de Doutoramento não Publicada, Faculdade de Psicologia e de Ciências da Educação da Universidade do Porto, Porto, 2012.

[14] V. E. Stone, J. W. Hogan and P. Schuman, “Antiretroviral Regimen Complexity, Self-Reported Adherence, and HIV Patients' Understanding of Their Regimens: Survey of Women in the HER Study," Journal of Acquired Immune Deficiency Syndromes, Vol. 28, 2001, p. 12.

[15] I. Al-Dakkak, S. Patel, E. McCann, A. Gadkari, G. Prajapati and E. M. Maiese, "The Impact of Specific HIV Treatment-Related Adverse Events on Adherence to Antiretroviral Therapy: A Systematic Review and MetaAnalysis. AIDS Care, 2012.

[16] A. Reis, L. Lencastre, M. Guerra and E. Remor, "Adaptação Portuguesa do Questionário para Avaliação da Adesão ao Tratamento Antiretrovírico-VIH (CEAT-VIH)," Psicologia, Saúde \& Doenças, Vol. 10, No. 2, 2009, pp. 175191.

[17] A. Vaz Serra, M. C. Canavarro, M. Simões, M. Pereira, S. Gameiro, et al., "Estudos Psicométricos do Instrumento de Avaliação da Qualidade de Vida da Organização Mundial da Saúde (WHOQOL-Bref) Para Português de Portugal," Psiquiatria Clínica, Vol. 27, No. 1, 2006, pp. 41-49.

[18] Centre for Disease Control, "Revised Classification System for HIV Infection and Expanded Surveillance Case Definition for AIDS among Adolescents and Adults," 1993.

www.heart-intl.net/Heart/HIV/Comp/SurvaillanceCaseDe finition1993.pdf

[19] E. Remor, "Manual del Cuestionario para la Evaluación de la Adhesión al Tratamiento Antirretroviral en Personas con Infección por VIH Y Sida. Guía para el usuario del Cuestionario para la Evaluación de la Adhesión al Tratamiento Antirretroviral en Personas con Infección por VIH Y Sida (CEAT-VIH)," Facultad de Psicología/Universidad Autónoma de Madrid, Madrid, 2009.
[20] M. L. Urbina, "Evaluación de Factores Asociados a la Baja Adherencia al TAR en Personas con VIH/SIDA, Porcentajes de Ocurrencia y Resultado del Desarrollo de Estratégias Según Hallazgos, en Correlación con la Carga Viral. Comunicação Apresentada ao VI Encuentro Nacional de Investigación en Enfermedades Infeciosas de la Asociación Colombiana de Infectologia. Santa Marta, Colombia, 2008.

[21] E. Remor, "International Psychometric Study of the Adherence to Antiretroviral Treatment Questionnaire," $\mathrm{Pa}$ per presented at 22nd Annual Conference of the European Health Psychology Society \& 11th Annual Conference of the BPS Division of Health Psychology, Bath, 2008.

[22] E. Tafur-Valderrama, C. Ortiz, C. O. Alfaro, E. GarcíaJímenez and M. J. Faus, "Adaptación del Cuestionario de Evaluación de la Adhesión al Tratamento Antiretroviral CEAT-VIH para su uso en Peru," ARS Pharmaceutica, Vol. 49, No. 3, 2008, pp. 183-198.

[23] A. Dima, A. M. Schweitzer, R. Neculau, E. Remor and S. Wanless, "Adherence to Antiretroviral Medication in Romanian Adolescents: Adaptation of CEAT-VIH Questionnaire," Poster Presented at the 24th Annual Conference of the European Health Psychology Society, Cluj, Romania, 2010.

[24] X. Gao, P. Nau, S. Rosenbluth, V. Scott and C. Woodward, "The Relationship of Disease Severity, Health Beliefs and Medication Adherence among HIV Patients," AIDS Care, Vol. 12, No. 4, 2000, pp. 387-398.

[25] J. J. Parienti, D. R. Bangsberg, R. Verdon and E. M. Gardner, "Better Adherence with Once-Daily Antiretroviral Regimens: A Meta-Analysis," Clinical Infectious Diseases, Vol. 48, No. 4, 2009, pp. 484-488.

[26] M. J. Atkinson and J. J. Petrozzino, “An Evidence-Based Review of Treatment-Related Determinants of Patients' Nonadherence to HIV Medications," AIDS Patient Care STDS, Vol. 23, No. 1, 2009, pp. 903-914.

[27] S. Bangalore, G. Kamalakkannan and S. Parkar, "FixedDose Combinations Improve Medication Compliance: A Meta-Analysis," The American Journal of Medicine, Vol. 120, 2007, pp. 713-719.

[28] F. Pulido, E. Ribera, S. Moreno, A. Munoz, D. Podzamczer, et al., "Once-Daily Antiretroviral Therapy: Spanish Consensus Statement," Journal of Antimicrobial Chemotherapy, Vol. 56, No. 5, 2005, pp. 808-818.

[29] K. Berg, A. Demas, A. Howard, E. Schoenbaum, M. Gourevitch and J. Arnsten, "Gender Differences in Factors Associated with Adherence to Antiretroviral Therapy," Journal of General Internal Medicine, Vol. 19, 2004, pp. 1111-1117.

[30] A. Reis, L. Lencastre, M. Guerra and E. Remor, "Relação Entre Sintomatologia Psicopatológica, Adesão ao Tratamento e Qualidade de vida na Infeção Pelo HIV e AIDS," Psicologia: Reflexão \& Crítica, Vol. 23, No. 3, 2010, pp. 420-429.

[31] L. Campos, C. César and M. Guimarães, "Quality of Life among HIV-Infected Patients in Brazil after Initiation of Treatment," Clinic Science, Vol. 64, No. 9, 2009, pp. 867-875. 
[32] G. Jones, K. Hawkins, R. Mullin, T. Nepusz, D. P. Naughton, et al., "Understanding How Adherence Goals Promote Adherence Behaviours: A Repeated Measure Ob- servational Study with HIV Seropositive Patients," BMC Public Health, Vol. 12, 2012, p. 587. 